\title{
Characterization of chemical compounds and antioxidant activity of Centaurea solstitialis ssp. schouwii (DC.) Q. et S. (Asteraceae)
}

\author{
Lamia Aliouche $^{\mathrm{a}}$, Paul Mosset ${ }^{\mathrm{b}}$, Francisco León ${ }^{\mathrm{c}, \mathrm{d}}$, Ignacio Brouard ${ }^{\mathrm{c}}$, Samir Benayache ${ }^{\mathrm{a}}$, Djamel Sarri ${ }^{\mathrm{e}}$ \\ and Fadila Benayache ${ }^{\mathrm{a}^{*}}$ \\ ${ }^{a}$ Unité de recherche:Valorisation des Ressources Naturelles, Molécules Bioactives et Analyses Physicochimiques et \\ Biologiques. Université Frères Mentouri, Constantine 1, Route d'Ä̈n El Bey, 25000, Constantine, Algeria; \\ aliouche@yahoo.com (L.M.); sbenayache@yahoo.com (S.B.); fbenayache@yahoo.fr; (F.B.). ${ }^{b}$ Université de Rennes, CNRS, \\ ISCR (Institut des Sciences Chimiques de Rennes), UMR 6226, F-35700, Rennes, France.paul.mosset.1@ univ-rennes1.fr. \\ ${ }^{c}$ Instituto de Productos Naturales y Agrobiología, C. S. I. C., Av. Astrofísico Francisco Sánchez, 3, 38206 La Laguna, \\ Tenerife, Spain; jfleon.oyola@gmail.com; (F.L.); ibrouard@ipna.csic.es; (I.B.). ${ }^{d}$ Department of Medicinal Chemistry, \\ College of Pharmacy, University of Florida, Gainesville 32610 Fl, USA; jleonoyola @ cop.ufl.edu. ${ }^{e}$ Département des \\ Sciences de la Nature et de la Vie, Faculté des Sciences, Université Mohamed Boudiaf, M'Sila, Algeria; \\ djamel_sarri@yahoo.fr.
}

\begin{abstract}
Background: The antioxidant activity and the total phenolic and flavonoid contents of the derived extracts (chloroform, ethyl acetate and $n$-butanol) of the $70 \%$ hydroalcoholic extract of the aerial parts of Centaurea solstitialis growing in Algeria was assessed. The active extracts were selected for phytochemical investigations.
\end{abstract}

Methods: The antioxidant capabilities of the extracts were assessed using 1,1-diphenyl-2-picrylhydrazyl radical (DPPH ${ }^{\circ}$ scavenging and cupric ion reducing antioxidant capacity (CUPRAC) assays. Butylhydroxyanisole (BHA), butylhydroxytoluene (BHT) and $\alpha$-tocopherol were used as positive controls. The total phenolic content and total flavonoid content of the extracts were determined as gallic acid equivalents and quercetin equivalents respectively. Chromatographic methods were used to isolate the secondary metabolites and spectrometric and spectroscopic methods were used to determine their chemical structures.

Results: The ethyl acetate extract exhibited the highest antioxidant activities followed by the $n$-butanol extract. The highest phenolic and flavonoid contents were found in the $n$-butanol extract. Phytochemical study of the ethyl acetate and n-butanol extracts led to the isolation of an undescribed guaianolide named 3-(4hydroxybenzoyl)-cynaratriol and a known sesquiterpene lactone along with three known flavonoid glycosides. Their structures were established by spectral analyses mainly high resolution electrospray ionisation mass spectrometry (HR-ESIMS) and 1D and 2D nuclear magnetic resonance experiments.

Conclusion: The extracts of aerial part of C. solstitialis showed significant antioxidant activities. An undescribed sesquiterpene lactone and four known secondary metabolites were isolated from the most active extracts.

Keywords: Centaurea solstitialis, Sesquiterpene lactones, Flavonoids, Antioxidant activity, Total phenolic and flavonoid contents.

\section{INTRODUCTION}

Numerous Centaurea species (Asteraceae) are used in folk medicine and reported various biological properties [1-7]. Moreover, several Centaurea plants has been recognized as excellent accumulators of bioactives molecules [8, 9]. Centaurea solstitialis L. and C. solstitialis L. ssp. solstitialis

have been reported to contain triterpenoids [10], flavonoids [11], sesquiterpene lactones [12-14], with sufficient biological effects [15-18].

The essential oil of the aerial parts of $C$. solstitialis ssp.

*Address correspondence to this author at the VARENBIOMOL Research Unit, Department of Chemistry, Faculty of Exact Sciences University Frères Mentouri Constantine 1, Constantine, Algeria; Tel/Fax: +21331811103;

E-mail: fbenayache@yahoo.fr

solstitialis collected from Kovancilar province, in Turkey

[19] exhibited $\beta$-eudesmol (15.5\%), bicyclogermacrene (14.2\%), spathulenol (11.3\%), germacrene D (6.3\%), caryophyllene oxide $(5.2 \%)$, hexadecanal $(4.2 \%)$ and hexadecanoic acid $(4.1 \%)$ as the most abundant components. Sesquiterpene lactones 
have been reported from C. solstitialis L. ssp. schouwii [20]. From the aerial parts of $C$. solstitialis L. ssp. schouwii Dostál collected at Piano Battaglia (Palermo) Italy, lignans and sesquiterpene lactones have been described [21], while the analysis of the chemical composition of the essential oil of its flower heads showed that fatty acids and their esters (43.6\%) and hydrocarbons (28.0\%) were the major constituents [22]. Moreover C. solstitialis L. ssp. schouwii (DC.) Gugler is used in Sicily (Italy) for food purposes and recognized as having medicinal properties [23]. As part of our ongoing phytochemical and biological program studies on Asteraceae family [24, 25] and notably Centaurea species growing in Algeria [26-30], we report in this paper a detailed study on the antioxidant activity of the derived extracts (chloroform, ethyl acetate and $n$-butanol) of the $70 \%$ ethanol extract of its aerial parts, the total phenolic content (TPC) and total flavonoid content (TFC) of the three extracts, as well as the fractionation, separation and purification of secondary metabolites of the ethyl acetate (EtOAc) and $n$-butanol (n$\mathrm{BuOH}$ ) extracts of $C$. solstitialis ssp. schouwii (DC.) Q. et S. (synonym: C. shouwii (DC.).

\section{MATERIALS AND METHODS}

\subsection{Experimental}

NMR spectra were obtained by Bruker AMX-500 spectrometer with standard pulse sequences, operating at $500 \mathrm{MHz}$ for ${ }^{1} \mathrm{H}$ and $125 \mathrm{MHz}$ for ${ }^{13} \mathrm{C}$. MeOH- $d_{4}$, was used as solvent and TMS as internal standard. HR-ESIMS was performed with a LCT Premier XE Micromass Waters spectrometer in positive ionization mode (Waters Corporation). Column chromatography (CC) was carried out with silica gel Fluka (cat. 60737) $(40-63 \mu \mathrm{m})$, and column fractions were monitored by thin layer chromatography (TLC) silica gel $60 \mathrm{~F}_{254}, 0.2 \mathrm{~mm}$, Macherey Nagel (cat. 818-333) by detection with a spraying reagent $\left(\mathrm{CH}_{3} \mathrm{COOH} / \mathrm{H}_{2} \mathrm{O} / \mathrm{H}_{2} \mathrm{SO}_{4} ; 80: 16: 4\right)$ followed by heating at $100{ }^{\circ} \mathrm{C}$. Preparative TLC was carried out on silica gel $60 \mathrm{PF}_{254}+366$ $(20 \times 20 \mathrm{~cm}, 1 \mathrm{~mm}$ thickness, Analtech cat. 02014).

\subsection{Plant material}

Centaurea solstitialis ssp. schouwii (DC.) Q. et S. was collected from El Kala in the eastern Algeria (GPS-coordinates: $36^{\circ}$ 53' 25.644" N 8० 26' 42.275" E) in June 2006 and authenticated by Dr. D. Sarri (University of M'Sila) on the basis of Quezel and Santa (1963) [31]. A sample has been deposited in the Herbarium of the Research Unit: Valorisation des Ressources Naturelles, Molécules Bioactives et Analyses Physicochimiques et Biologiques (VARENBIOMOL), Université Frères Mentouri Constantine 1.

\subsection{Extraction and isolation}

Air-dried and powdered aerial parts from C. solstitialis ssp. schouwii (DC.) Q. et S. (1200 g) were extracted with EtOH- $\mathrm{H}_{2} \mathrm{O}$ $(70: 30 \mathrm{v} / \mathrm{v})$ for 24 hours, three times. The crude extract was concentrated under reduced pressure up to $35^{\circ} \mathrm{C}(500 \mathrm{~mL})$, diluted with $480 \mathrm{~mL}$ distilled $\mathrm{H}_{2} \mathrm{O}$ under magnetic stirring and then, kept at $4^{\circ} \mathrm{C}$ for one night to precipitate a maximum of chlorophylls. After filtration the remaining aqueous solution was extracted successively with petroleum ether, chloroform $\left(\mathrm{CHCl}_{3}\right)$, EtOAc and $n$-BuOH. The organic layers were dried with $\mathrm{Na}_{2} \mathrm{SO}_{4}$ giving after removal of solvents under reduced pressure (up to $\left.35^{\circ} \mathrm{C}\right)$ petroleum ether $(0.51 \mathrm{~g}), \mathrm{CHCl}_{3}(8 \mathrm{~g})$, EtOAc $(10.5 \mathrm{~g})$ and $n$ - $\mathrm{BuOH}(17 \mathrm{~g})$ extracts. EtOAc extract $(10 \mathrm{~g})$ was fractionated by column chromatography (CC) on silica gel using chloroform with increasing percentages of methanol to yield 33 fractions (1-33) obtained by combining the eluates on the basis of TLC analysis. Fraction 10 (96:4) gave after evaporation, the pure compound (1) as white crystals $(105 \mathrm{mg})$ identified as $4 \beta, 15$ - dihydro-3-dehydrosolstitialin A. Fraction $15(54 \mathrm{mg})(92: 8)$ gave after purification on preparative plates of silica gel $\left(\mathrm{CHCl}_{3} / \mathrm{MeOH}, 9: 1\right)$ the new sesquiterpene lactone (2) $(32 \mathrm{mg}$ ). Fraction 19 (99 mg, 88:12) was subjected to successive purifications on TLC preparative to give kaempferol 3-Orhamnoside (3) (45 mg). A part of the $n$ - $\mathrm{BuOH}$ extract (12 g) was subjected to $\mathrm{CC}$ on silica gel eluted with $\mathrm{CHCl}_{3} / \mathrm{MeOH}$ step gradients and then with increasing percentages of $\mathrm{H}_{2} \mathrm{O}$ ) to yield 55 fractions (1-55) obtained by combining the eluates on the basis of TLC behavior. Fraction 18 (170 mg, 90:10) was purified on TLC plates (EtOAc/MeOH/ $\left.\mathrm{H}_{2} \mathrm{O}, 8: 1: 1\right)$ to give astragalin (4) $(17.7 \mathrm{mg})$, and 6-methoxy kaempferol-3-O-glucopyranoside (5) (12.8 mg).

\subsection{Determination of total bioactive compounds}

\section{Determination of total phenolic content $(T P C)$}

The total phenolic contents of the three extracts from C. solstitialis ssp. schouwii (DC.) Q. et S., were determined by FolinCiocalteu reagent method [32]. The absorbance of the sample was read at the wavelength $765 \mathrm{~nm}$. Standard solutions of gallic acid with concentrations 25 to $200 \mu \mathrm{g} / \mathrm{mL}$ were used to obtain the standard curve. The results were determined from the standard curve and expressed as mg gallic acid equivalents per gram of dry extract (mg GAE/g dry extract). Analyses were done in triplicate for each extract. 
The total flavonoid contents of the three extracts were determined spectrophotometrically as previously reported [33]. The absorbance was read at the wavelength $415 \mathrm{~nm}$. Standard solutions of quercetin with concentration 25 to $200 \mu \mathrm{g} / \mathrm{mL}$ were used to obtain the standard curve, and the results were expressed as mg quercetin equivalents per gram of dry extract (mg QE/g extract). All the experiments were carried out in triplates.

\subsection{Determination of antioxidant activity}

\section{DPPH scavenging assay}

The DPPH scavenging activity was determined spectrophotometrically in accordance with the method described by Blois [34]. Butylhydroxyanisole (BHA), butylhydroxytoluene (BHT) and $\alpha$-tocopherol were used as antioxidant standards for comparison of the activity. The scavenging activity of DPPH radical was calculated using the following equation:

DPPH scavenging effect $(\%)=\left[\left(\mathrm{A}_{\text {control }}-\mathrm{A}_{\text {sample }}\right) / \mathrm{A}_{\text {control }}\right] \times 100$

Where $A_{\text {Control }}$ is the absorbance of the initial concentration of the DPPH and $A_{\text {sample }}$ is the absorbance of the remaining concentration of DPPH in the presence of the extract or positive controls. The results were given as $\mathrm{IC}_{50}$ value $(\mu \mathrm{g} / \mathrm{mL})$ corresponding to the concentration of $50 \%$ inhibition.

\section{Cupric reducing antioxidant capacity (CUPRAC)}

The cupric reducing antioxidant capacity was determined according to the method described by Apak [35]. The reducing capacity of the extracts was compared with those of BHA and BHT. The results were given as $A_{0.5}(\mu \mathrm{g} / \mathrm{mL})$ corresponding to the concentration indicating 0.50 absorbance intensity.

\section{RESULTS AND DISCUSSION}

\subsection{Structure elucidation of compounds 1-5}

After separation and purification by chromatographic procedures, five compounds: a new guaianolide and four known secondary metabolites were isolated from the ethyl acetate and $n$-butanol soluble parts of the hydroalcoholic extract of the aerial parts of Centaurea solstitialis ssp. schouwii (DC.) Q. et S. The structures of all the compounds were established by spectral analyses, mainly UV-Vis, ESI-HRMS, ${ }^{1} \mathrm{H}-\mathrm{NMR},{ }^{13} \mathrm{C}-\mathrm{NMR}$, and 2D-NMR (COSY, NOESY, HSQC and HMBC) (Fig. 1).

Compound 2 gave a molecular formula $\mathrm{C}_{22} \mathrm{H}_{26} \mathrm{O}_{7}$ deduced from its TOF-HR-ESIMS $m / z 421.1483\left[\mathrm{M}+\mathrm{H}_{3} \mathrm{O}\right]^{+}$indicating ten degrees of unsaturation in it. Its NMR spectra were very similar to those of cynaratriol, a sesquiterpene lactone with a guaianolide skeleton type isolated in particular from Cynara cardunculus L. [36] and from Centaurea musimomum (musimonum) [37, 38]. The difference found in the ${ }^{1} \mathrm{H}$ NMR spectrum of this compound compared to that of cynaratriol was the appearance of two additional resonances corresponding to two doublets of $2 \mathrm{H}$ each at $\delta_{\mathrm{H}} 7.72$ and $\delta_{\mathrm{H}} 6.63(J=8.7 \mathrm{~Hz})$. These signals were characteristic of a para-substituted aromatic ring. The ${ }^{13} \mathrm{C}$ NMR and DEPT experiment spectra when compared to those of cynaratriol, confirmed this hypothesis by exhibiting additional resonances consisting in two signals of aromatic $\mathrm{CH}\left(\delta_{\mathrm{C}}\right.$ 132.33 and $115.26 \mathrm{ppm}$ and two quaternary carbon atoms at $\delta_{\mathrm{C}} 128.90$ and $\delta_{\mathrm{C}} 160.91 \mathrm{ppm}$ (Table $\mathbf{1}$ ). The values of the chemical shifts of these two last carbons corresponded to a nonoxygenated and an oxygenated aromatic quaternary carbons. These assumptions were consolidated by the observed correlations between the protons of the aromatic $\mathrm{CH}$ groups in the COSY spectrum and between the quaternary carbon at $\delta_{\mathrm{C}} 128.90$ and the protons of the doublet at $\delta_{\mathrm{H}} 6.63$ and between the quaternary carbon at $\delta_{\mathrm{C}} 160.91$ and the protons of the doublet at $\delta_{\mathrm{H}} 7.72$ in the HMBC experiment spectrum. These observations permitted the assignment of these quaternary carbons to $\mathrm{C}-1$ ' and C-4', respectively and the assignment of the two $2 \mathrm{H}$ doublets to $\mathrm{H}-3$ ', H-5' and H-2', H-6', respectively of this aromatic cycle (Table 1). In fact, the combination of the molecular formula $\left(\mathrm{C}_{22} \mathrm{H}_{26} \mathrm{O}_{7}\right)$ and the NMR spectral data revealed the presence in this molecule of a para-hydroxybenzoate group instead a hydroxyl group in cynaratriol. The carbon of the carbonyl of this group (C-7') was deduced at $\delta_{C} 171.54$ from the correlation with H-2' and H-6' found in the HMBC spectrum. The analyses of all the NMR spectra led in particular, to the assignment of $\mathrm{H}_{3}-15, \mathrm{H}-2 \alpha, \mathrm{H}-2 \beta$, $\mathrm{H}-4 \beta, \mathrm{H}-3, \mathrm{H}-14 \mathrm{a}$ and $\mathrm{H}-14 \mathrm{~b}$ of the guaianolide skeleton, to the signals at $\delta_{\mathrm{H}} 1.10\left(\mathrm{~d}, J=6.3 \mathrm{~Hz}, \delta_{\mathrm{C}} 18.72\right), \delta_{\mathrm{H}} 1.97\left(\mathrm{~m}, \delta_{\mathrm{C}}\right.$ $39.33), \delta_{\mathrm{H}} 1.60\left(\mathrm{~m}, \delta_{\mathrm{C}} 39.33\right), \delta_{\mathrm{H}} 1.65\left(\mathrm{~m}, \delta_{\mathrm{C}} 47.76\right), \delta_{\mathrm{H}} 3.53\left(\mathrm{~m}, \delta_{\mathrm{C}} 78.92\right), \delta_{\mathrm{H}} 4.83\left(\mathrm{~s}, \delta_{\mathrm{C}} 112.53\right)$ and $\delta_{\mathrm{H}} 4.80\left(\mathrm{~s}, \delta_{\mathrm{C}} 112.53\right)$ respectively. In the NOESY experiment spectrum, pertinent correlations were observed between protons of the guaianolide skeleton and the protons of the aromatic ring of the $p$ - hydroxybenzoyl group notably: $\mathrm{H}_{3}-15 / \mathrm{H}-2^{\prime}, \mathrm{H}-6^{\prime} ; \mathrm{H}-2 \beta / \mathrm{H}^{\prime}, \mathrm{H}^{\prime} 5^{\prime}, \mathrm{H}^{-}$ 2', H-6'; H-4ß/H-3', H-5'; H-3/H-3', H-5' and H-14a, H-14b/H-2', H-6', H-3', H-5'. From the presence of these correlations, we conclude that the $p$-hydroxybenzoate group is connected in C-3 of the guaianolide skeleton and has a $\beta$-orientation. Thus compound 2 was identified as a new derivative of cynaratriol named 3-(4-hydroxybenzoyl)-cynaratriol. This result agreed with literature data where guaianolides bearing 4-hydroxybenzoate group have been reported from Acroptilon repens [39] and Centaurea glastifolia [40] of Asteraceae family. The known compounds were characterized by comparison of their spectral data with those reported in literature.

Table 1. NMR data $\left(\mathrm{MeOH}-d_{4}\right),{ }^{1} \mathrm{H}(500 \mathrm{MHz}, J / \mathrm{Hz}),{ }^{13} \mathrm{C}(125 \mathrm{MHz})$ of compound 2 


\begin{tabular}{|c|c|c|}
\hline Position & $\delta \mathrm{c}(\mathbf{p p m})$ & $\delta н(p p m)$ \\
\hline 1 & 43.04 & $\mathrm{H}-1 \alpha 2.70 \mathrm{~m}$ \\
\hline & & $\mathrm{H}-2 \alpha 1.97 \mathrm{~m}$ \\
\hline 2 & 39.33 & $\mathrm{H}-2 \beta 1.60 \mathrm{~m}$ \\
\hline 3 & 78.92 & $\mathrm{H}-3 \alpha 3.53 \mathrm{~m}^{*}$ \\
\hline 4 & 47.76 & $\mathrm{H}-4 \beta 1.65 \mathrm{~m}$ \\
\hline 5 & 53.12 & H-5 $\alpha 1.78 m$ \\
\hline 6 & 86.15 & H-6 $34.08(t, 10.2)$ \\
\hline 7 & 56.13 & H-7a $2.10(d d d, 12.5,9.8,3.6))$ \\
\hline 8 & 28.13 & 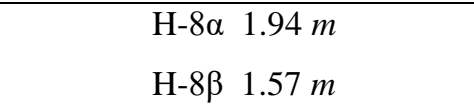 \\
\hline 9 & 38.01 & $\begin{array}{c}\mathrm{H}-9 \beta \quad 2.55(d t, 12.6,3.9) \\
\mathrm{H}-9 \alpha \quad 1.75 \mathrm{~m}\end{array}$ \\
\hline 10 & 151.37 & I \\
\hline 11 & 78.64 & I \\
\hline 12 & 180.93 & I \\
\hline 13 & 64.43 & 3.55 brs \\
\hline 14 & 112.53 & $\begin{array}{l}\mathrm{H}-14 \mathrm{a} 4.83 \text { brs } \\
\mathrm{H}-14 \mathrm{~b} 4.80 \mathrm{brs}\end{array}$ \\
\hline 15 & 18.72 & $1.10(d, 6.3)$ \\
\hline $2^{\prime}, 6^{\prime}$ & 132.33 & $7.72(d d, 8.7)$ \\
\hline $3^{\prime}, 5^{\prime}$ & 115.26 & $6.63(d d, 8.7)$ \\
\hline 1 ' & 128.90 & I \\
\hline 4 ' & 160.91 & I \\
\hline 7 ' & $171.54^{* *}$ & I \\
\hline
\end{tabular}

* : Partialy obscured by the signal of $\mathrm{H}_{2}-13 .{ }^{* *}$ : Not detected, deduced from HMBC spectrum.

4ß,15-dihydro-3-dehydrosolstitialin A (1): TOF-HRESIMS (+): $\mathrm{m} / z \quad 303.1203$ [M+Na] ${ }^{+}$(calculated for $\mathrm{C}_{15} \mathrm{H}_{20} \mathrm{O}_{5} \mathrm{Na}$ : 303.1208, formula $\mathrm{C}_{15} \mathrm{H}_{20} \mathrm{O}_{5} .{ }^{1} \mathrm{H}-\mathrm{NMR}\left(400 \mathrm{MHz}, \mathrm{CD}_{3} \mathrm{OD}\right) \delta_{\mathrm{H}}(\mathrm{ppm}): 1.20(3 \mathrm{H}, \mathrm{d}, J=6.7 \mathrm{~Hz}, \mathrm{H} 3-15), 1.81(1 \mathrm{H}, \mathrm{qd}, J=12.5,5.0 \mathrm{~Hz}, \mathrm{H}-$ $8 \beta), 2.13(1 \mathrm{H}, \mathrm{m}, \mathrm{H}-9 \alpha), 2.17(1 \mathrm{H}, \mathrm{m}, \mathrm{H}-8 \alpha), 2.25(1 \mathrm{H}, \mathrm{brt}, J=8.5 \mathrm{~Hz}, \mathrm{H}-5 \alpha), 2.33(1 \mathrm{H}, \mathrm{m}, \mathrm{H}-4 \beta), 2.34$ (2H, brs, 11-OH and 13-OH), $2.45(1 \mathrm{H}, \mathrm{dd}, J=19.0,3.6 \mathrm{~Hz}, \mathrm{H}-2 \beta), 2.54(1 \mathrm{H}, \mathrm{m}, \mathrm{H}-7 \alpha), 2.61(1 \mathrm{H}, \mathrm{dd}, J=19.0,7.8 \mathrm{~Hz}, \mathrm{H}-2 \alpha), 2.67(1 \mathrm{H}, \mathrm{m}, \mathrm{H}-9 \beta)$, $3.18(1 \mathrm{H}, \mathrm{ddd}, J=8.5,7.8,3.6 \mathrm{~Hz}, \mathrm{H}-1 \alpha), 3.69(1 \mathrm{H}, \mathrm{d}, J=10.5 \mathrm{~Hz}, \mathrm{H}-13 \mathrm{~b}), 3.72(1 \mathrm{H}, \mathrm{d}, J=10.5 \mathrm{~Hz}, \mathrm{H}-13 \mathrm{a}), 4.23(1 \mathrm{H}, \mathrm{dd}, J=$ 9.9, $8.5 \mathrm{~Hz}, \mathrm{H}-6 \beta$ ), $4.65(1 \mathrm{H}, \mathrm{s}, \mathrm{H}-14 \mathrm{~b}), 5.00(1 \mathrm{H}, \mathrm{s}, \mathrm{H}-14 \mathrm{a}) .{ }^{13} \mathrm{C}-\mathrm{NMR}\left(100 \mathrm{MHz}, \mathrm{CD}_{3} \mathrm{OD}\right) \delta_{\mathrm{C}}(\mathrm{ppm}): 14.48(\mathrm{C}-15), 28.00$ (C8), 39.95 (C-9), 41.00 (C-1), 44.92 (C-2), 48.49 (C-4), 51.23 (C-7), 52.84 (C-5), 64.59 (C-13), 88.69 (C-6), 78,64 (C-11), 112.43 (C-14), 151.54 (C-10), 180.77 (C-12), 222.05 (C-3). All these data were in good agreement with those reported for the same molecule isolated from Centaurea musimomum [41].

Kaempferol 3-O-rhamnoside (3): $\mathrm{C}_{21} \mathrm{H}_{20} \mathrm{O}_{10}, \mathrm{UV}\left(\mathrm{MeOH}, \lambda_{\max }, \mathrm{nm}\right)$ : 266, 350; $+\mathrm{NaOH}$ : 275, 324, 401 (with hyperchromic effect); $+\mathrm{AlCl}_{3}: 272,305,352,398 ;+\mathrm{AlCl}_{3}+\mathrm{HCl}: 274,302,344,397 ;+\mathrm{NaOAc:} 273,306,374 ;+\mathrm{NaOAc}+\mathrm{H}_{3} \mathrm{BO}_{3}: 267,356 .{ }^{1} \mathrm{H}-$ NMR (300 MHz, CD $\left.{ }_{3} \mathrm{OD}\right) \delta_{\mathrm{H}}(\mathrm{ppm})$ aglycone: $7.79\left(2 \mathrm{H}, \mathrm{d}, J=7.9 \mathrm{~Hz}, \mathrm{H}-2^{\prime}\right.$ ' and H-6'), 6.96 (2H, d, $J=7.9 \mathrm{~Hz}, \mathrm{H}-3$ ' and H-5'), $6.39(1 \mathrm{H}, \mathrm{d}, J=2.0 \mathrm{~Hz}, \mathrm{H}-8), 6.22(1 \mathrm{H}, \mathrm{d}, J=2.0 \mathrm{~Hz}, \mathrm{H}-6)$, sugar moiety: 5.39 (1H, d, $J=1.2 \mathrm{~Hz}, \mathrm{H}-1$ ”), $0.94(3 \mathrm{H}, \mathrm{d}, J=6.5$ $\mathrm{Hz}, \mathrm{H}_{3-}$ '"), the complete identity of the sugar was established by acidic hydrolysis and co-chromatography with authentic samples of various sugar molecules. All the obtained spectroscopic data were in accordance with those reported in the literature for the same compound isolated from the leaves of Schima wallichii Korth. [42].

Astragalin (4): $\mathrm{C}_{21} \mathrm{H}_{20} \mathrm{O}_{11},{ }^{1} \mathrm{H}-\mathrm{NMR}\left(500 \mathrm{MHz}, \mathrm{CD}_{3} \mathrm{OD}\right) \delta_{\mathrm{H}}(\mathrm{ppm})$ aglycone: 8.07 (2H, d, $J=8.8 \mathrm{~Hz}, \mathrm{H}-2$ ' and H-6'), 6.90 (2H, d, $J=8.8 \mathrm{~Hz}, \mathrm{H}-3$ ' and $\mathrm{H}-5$ ') $6.37(1 \mathrm{H}, \mathrm{d}, J=2.0 \mathrm{~Hz}, \mathrm{H}-8), 6.20(1 \mathrm{H}, \mathrm{d}, J=2.0 \mathrm{~Hz}, \mathrm{H}-6), O-\beta$-glucopyranoside moiety: 5.18 
$(1 \mathrm{H}, \mathrm{d}, J=7.3 \mathrm{~Hz}, \mathrm{H}-1$ "), 4.60 (1H, dd, $J=12.0,2.3 \mathrm{~Hz}, \mathrm{H}-6 ” \mathrm{a}), 4.46$ (1H, dd, $J=12.0,5.4 \mathrm{~Hz}, \mathrm{H}-6$ ”b), 3.35 (m,1H, H-2"), 3.34 (m, 1H, H-3"), 3.24 (H-4", obscured by the signal of the solvent, deduced from COSY and HSQC spectra), $3.12(1 \mathrm{H}, \mathrm{m}$, H-5"). ${ }^{13} \mathrm{C}-\mathrm{NMR}\left(125 \mathrm{MHz}, \mathrm{CD}_{3} \mathrm{OD}\right) \delta_{\mathrm{C}}(\mathrm{ppm})$ aglycone: $178.08(\mathrm{C}-4), 164.68$ (C-7), $161.53(\mathrm{C}-5), 160.29(\mathrm{C}-4$ '), $157.70(\mathrm{C}-$ 2), 157.09 (C-9), 134.20 (C-3), 131.19 (C-2' and C-6'), 121.36 (C-1'), 114.98 (C-3' and C-5'), 104.39 (C-10), 98.78 (C-6),

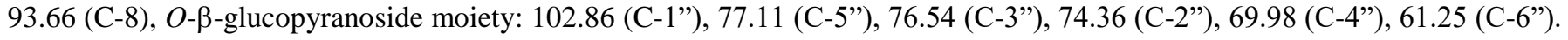
These data were in perfect agreement with those reported for astragalin isolated from Helianthemum ruficomum [43].

6-Methoxy kaempferol 3-O- $\beta$-glucopyranoside (5): $\mathrm{C}_{22} \mathrm{H}_{22} \mathrm{O}_{12},{ }^{1} \mathrm{H}-\mathrm{NMR}\left(400 \mathrm{MHz}, \mathrm{CD}_{3} \mathrm{OD}\right) \delta_{\mathrm{H}}(\mathrm{ppm})$ aglycone: 8.04 (2H, d, $J$ $=8.8 \mathrm{~Hz}, \mathrm{H}-2^{\prime}$ and $\left.\mathrm{H}^{\prime} 6^{\prime}\right), 6.88(2 \mathrm{H}, \mathrm{d}, J=8.8$

$\mathrm{Hz}, \mathrm{H}-3$ ' and H-5'), $6.48(1 \mathrm{H}, \mathrm{s}, \mathrm{H}-8), 3.87$ ( $\left.3 \mathrm{H}, \mathrm{s}, \mathrm{OCH}_{3}\right), O-\beta$ - glucopyranoside moiety: $5.23(1 \mathrm{H}, \mathrm{d}, J=7.4 \mathrm{~Hz}, \mathrm{H}-1$ "), 3.68 (1H, dd, $J=11.9,2.2 \mathrm{~Hz}, \mathrm{H}-6$ "a), 3.53 (1H, dd, $J=11.9,5.4 \mathrm{~Hz}, \mathrm{H}-6$ "b), 3.45 (1H, m, H-2"), 3.43 (1H, m, H-3"), 3.30 (H-4", obscured by the signal of the solvent, deduced from the HMQC and HMBC spectra), $3.20\left(1 \mathrm{H}, \mathrm{m}, \mathrm{H}-5\right.$ ") ${ }^{13} \mathrm{C}-\mathrm{NMR}(100 \mathrm{MHz}$, $\left.\mathrm{CD}_{3} \mathrm{OD}\right) \quad \delta_{\mathrm{C}}(\mathrm{ppm})$ aglycone: $179.72(\mathrm{C}-4), 161.64$ (C-4'), 160.07 (C-7), 159.13 (C-2), 154.09 (C-5), 153.69 (C-9), 135.17 (C3), 133.08 (C-6), 132.32 (C-2' and C-6'), 122.91 (C-1'), 116.13 (C-3'and C-5'), 105.88 (C-10), 95.34 (C-8), $60.94\left(\mathrm{OCH}_{3}\right), O$ $\beta$-glucopyranoside moiety: 104.21 (C-1"), 78.48 (C-5"), 78.10 (C-3"), 75.78 (C-2"), 71.41 (C-4"), 62.63 (C-6"). All these data were in good agreement with those reported by Wei et al. (2004) [44] for the same compound isolated from Mikania micrantha.

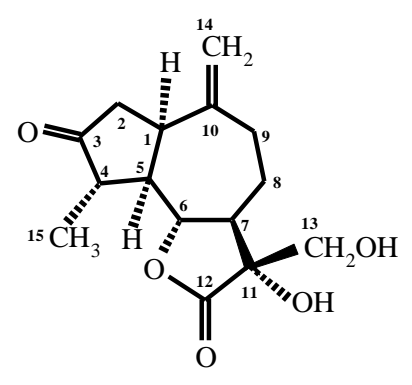

1

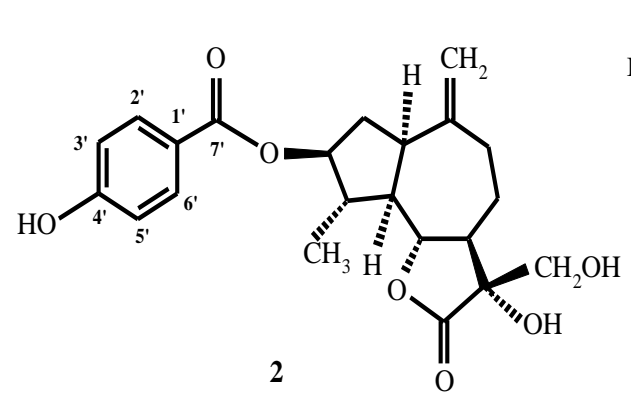

2

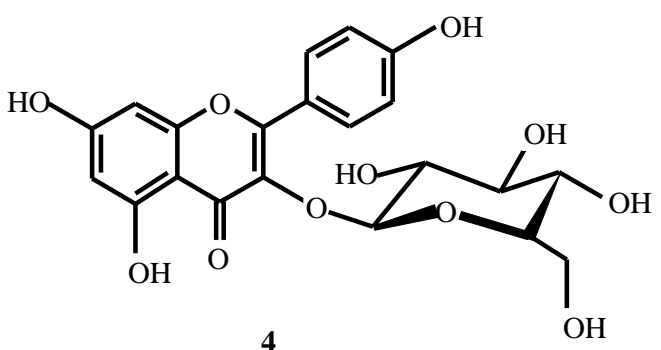

4

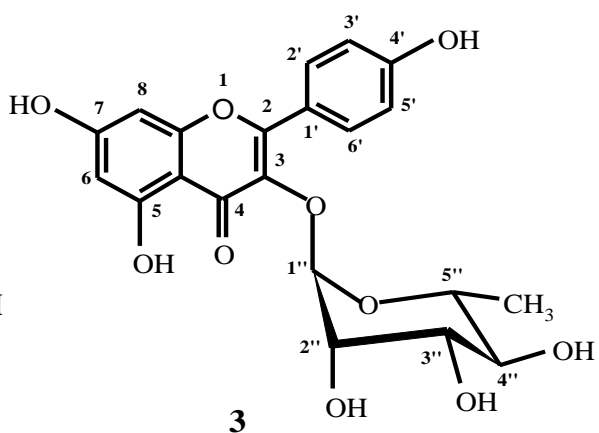

3<smiles>COc1c(O)cc2oc(-c3ccc(O)cc3)c(O[C@@H]3O[C@H](CO)C(O)C(O)[C@H]3O)c(=O)c2c1O</smiles>

5

Fig. (1). Structures of compounds 1-5 isolated from C. solstitialis ssp. schouwii (DC.) Q. et S.

\subsection{Determination of total bioactive compounds}

The TPC in various extracts were reported in term of gallic acid equivalents using the standard curve equation $\mathrm{y}=0.002 \mathrm{x}+$ $0.045, \mathrm{R}^{2}=0.997$. TPC in various extracts of $C$. solstitialis ssp. schouwii (DC.) Q. et S. showed different results ranged from $90.90 \pm 4.37$ to $130.20 \pm 4.71 \mathrm{mg} \mathrm{GAE} / \mathrm{g}$ of extract. The $n-\mathrm{BuOH}$ extract had the highest phenolic content $(130.20 \pm 4.71 \mathrm{mg}$ GAE/g) (Table 2, Fig. 2). TFC in various extracts were reported in term of quercetin equivalents using the standard curve equation $\mathrm{y}=0.006 \mathrm{x}+0.017, \mathrm{R}^{2}=0.976$. TFC in different extracts showed different results ranged from $8.2 \pm 0.57$ to $76.97 \pm$ $6.19 \mathrm{mgQE} / \mathrm{g}$ of extract (Table 2, Fig. 2). The $n$-BuOH extract had the highest TFC (76.97 $\pm 6.19 \mathrm{mgQE} / \mathrm{g}$ of extract); the lowest $(8.2 \pm 0.57 \mathrm{mgQE} / \mathrm{g}$ of extract) was given by the chloroform extract. 
Table 2. Total phenolic and flavonoid contents of the three extracts of $C$. solstitialis ssp. schouwii (DC.) Q. et S.

\begin{tabular}{|c|c|c|}
\hline Extracts & $\begin{array}{c}\text { Total phenolic content } \\
\text { (mgGAE/g extract) }\end{array}$ & $\begin{array}{c}\text { Total flavonoid content } \\
\text { (mgQE/g extract) }\end{array}$ \\
\hline Chloroform extract & $90.90 \pm 4.37$ & $8.2 \pm 0.57$ \\
\hline Ethyl acetate extract & $117.08 \pm 8.54$ & $54.31 \pm 2.87$ \\
\hline$n$-Butanol extract & $130.20 \pm 4.71$ & $76.97 \pm 6.19$ \\
\hline
\end{tabular}

Fig. (2). Total phenolic and total flavonoid contents in the three extracts of C. solstitialis ssp. schouwii (DC.) Q. et S.

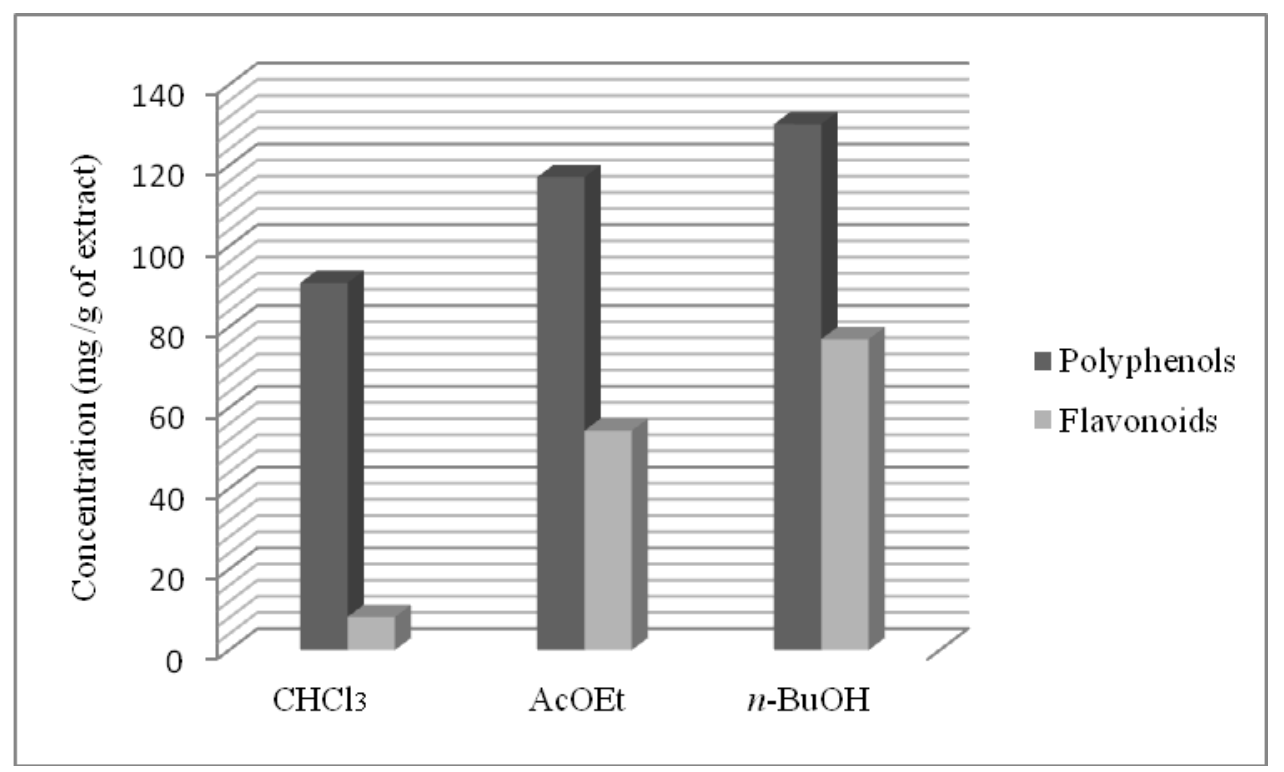

\section{Antioxidant activity}

There was no previous study regarding antioxidant activity of the three different polarity extracts (chloroform, ethyl acetate and $n$-butanol) from $C$. solstitialis ssp. schouwii (DC.) Q. et S. Two methods were selected to determine the antioxidant capacity of the extracts, DPPH free radical scavenging activity and the CUPRAC. The free radical scavenging activity of the extracts is illustrated in Fig. (3) and reported in Table 3. The values of three standard compounds BHA (IC 50 value: $6.14 \pm 0.41 \mu \mathrm{g} / \mathrm{mL}$ ), BHT (IC 50 value: $12.99 \pm 0.41 \mu \mathrm{g} / \mathrm{mL}$ ) and $\alpha$-tocopherol $\left(\mathrm{IC}_{50}\right.$ value: $13.02 \pm 5.17 \mu \mathrm{g} / \mathrm{mL}$ ), were obtained and compared to those of the studied extracts. The examination of antioxidant activities of the extracts from C. solstitialis ssp. schouwii (DC.) Q. et S.. showed different values, the ethyl acetate extract exhibited the highest activity (IC 50 value: $44.01 \pm$ $1.06 \mu \mathrm{g} / \mathrm{mL})$. A moderate activity was found for $n$ - BuOH extract $(65.46 \pm 3.07 \mu \mathrm{g} / \mathrm{mL})$. In comparison to IC $\mathrm{I}_{50}$ values of BHT and $\alpha$-Tocopherol, EtOAc extract exhibited the strongest capacity for neutralization of DPPH radicals (Table 3 ). 
Table 3. Antioxidant activity by the DPPH assaya.

\begin{tabular}{|c|c|c|c|c|c|c|c|c|}
\hline \multirow{2}{*}{$\begin{array}{l}\text { Extacts / } \\
\text { Concentratio } \\
\text { ns }\end{array}$} & \multicolumn{8}{|c|}{ \% Inhibition in DPPH assay } \\
\hline & $\begin{array}{c}12.5 \\
\mu \mathrm{g} / \mathrm{mL}\end{array}$ & $25 \mu \mathrm{g} / \mathrm{mL}$ & $50 \mu \mathrm{g} / \mathrm{mL}$ & $\begin{array}{c}100 \\
\mu \mathrm{g} / \mathrm{mL}\end{array}$ & $\begin{array}{c}200 \\
\mu \mathrm{g} / \mathrm{mL}\end{array}$ & $400 \mu \mathrm{g} / \mathrm{mL}$ & $800 \mu \mathrm{g} / \mathrm{mL}$ & $\begin{array}{c}\mathrm{IC}_{50} \\
\mu \mathrm{g} / \mathrm{mL}\end{array}$ \\
\hline $\mathrm{CHCl}_{3}$ extract & NA & NA & NA & $5.08 \pm 1.71$ & $\begin{array}{c}16.63 \pm 2.9 \\
3\end{array}$ & $27.80 \pm 0.59$ & $46.29 \pm 0.74$ & $<800$ \\
\hline EtOAc extract & $7.22 \pm 0.22$ & $\begin{array}{c}11.07 \pm 0.2 \\
2\end{array}$ & $\begin{array}{c}37.99 \pm 4.0 \\
4\end{array}$ & $\begin{array}{c}86.39 \pm 0.5 \\
6\end{array}$ & $\begin{array}{c}88.10 \pm 0.5 \\
3\end{array}$ & $88.27 \pm 0.71$ & $88.19 \pm 0.00$ & $44.01 \pm 1.06$ \\
\hline $\begin{array}{l}n-\mathrm{BuOH} \\
\text { extract }\end{array}$ & $3.32 \pm 0.77$ & $\begin{array}{c}14.36 \pm 3.2 \\
4\end{array}$ & $\begin{array}{c}34.61 \pm 3.9 \\
2 \\
\end{array}$ & $\begin{array}{c}81.60 \pm 1.9 \\
7 \\
\end{array}$ & $\begin{array}{c}88.06 \pm 0.6 \\
4\end{array}$ & $87.50 \pm 3.08$ & $88.70 \pm 0.00$ & $65.46 \pm 3.07$ \\
\hline $\mathrm{BHA}^{\mathrm{b}}$ & $\begin{array}{c}76.55 \pm 0.4 \\
8\end{array}$ & $\begin{array}{c}79.89 \pm 0.2 \\
6\end{array}$ & $\begin{array}{c}81.73 \pm 0.1 \\
0\end{array}$ & $\begin{array}{c}84.18 \pm 0.1 \\
0\end{array}$ & $\begin{array}{c}87.13 \pm 0.1 \\
7\end{array}$ & $89.36 \pm 0.19$ & $90.14 \pm 0.00$ & $6.14 \pm 0.41$ \\
\hline $\mathrm{BHT}^{\mathrm{b}}$ & $\begin{array}{c}49.09 \pm 0.7 \\
6\end{array}$ & $\begin{array}{c}72.63 \pm 2.0 \\
6\end{array}$ & $\begin{array}{c}88.73 \pm 0.8 \\
9\end{array}$ & $\begin{array}{c}94.00 \pm 0.3 \\
1\end{array}$ & $\begin{array}{c}94.97 \pm 0.0 \\
8\end{array}$ & $95.38 \pm 0.41$ & $95.02 \pm 0.23$ & $12.99 \pm 0.41$ \\
\hline$\alpha$-Tocopherol ${ }^{b}$ & $\begin{array}{c}37.21 \pm 1.8 \\
2\end{array}$ & $\begin{array}{c}81.53 \pm 1.5 \\
1\end{array}$ & $\begin{array}{c}89.23 \pm 0.1 \\
2 \\
\end{array}$ & $\begin{array}{c}89.38 \pm 0.1 \\
9 \\
\end{array}$ & $\begin{array}{c}89.45 \pm 0.2 \\
2 \\
\end{array}$ & $89.99 \pm 0.23$ & $89.52 \pm 0.33$ & $13.02 \pm 5.17$ \\
\hline
\end{tabular}

${ }^{a}$ Values expressed as means \pm S.D. of three parallel measurements. $(p<0.05)$.

${ }^{\mathrm{b}}$ Reference compounds. NA: no absorbance

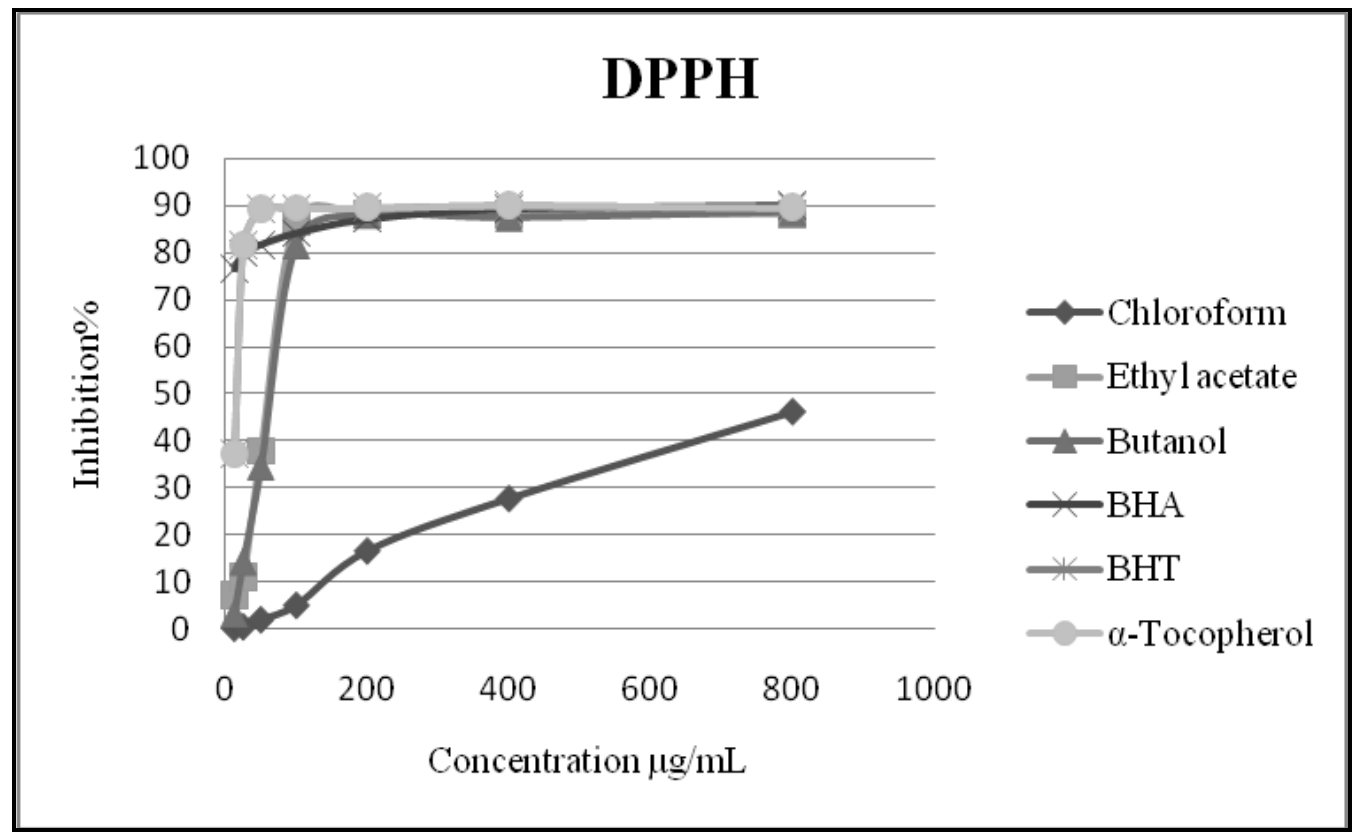

Fig. (3). DPPH radical scavenging activity of the three extracts, BHA, BHT and $\alpha$-Tocopherol at different concentrations (mean $\pm \mathrm{SD}, \mathrm{n}=3)$.

The results of CUPRAC of the extracts are compared with those of BHA and BHT (Fig. 4 and Table 4), the activity (absorbance) increased linearly with the increasing amount of extracts. The EtOAc extract exhibited the highest activity ( $\mathrm{A}_{0.50}$ value: $30.93 \pm 2.50 \mu \mathrm{g} / \mathrm{mL})$ among the extracts, followed by $n$-butanol extract $\left(\mathrm{A}_{0.50}\right.$ value: $\left.44.80 \pm 3.74 \mu \mathrm{g} / \mathrm{mL}\right)$ and chloroform 
extract $\left(\mathrm{A}_{0.50}\right.$ value: $\left.515.33 \pm 39.56 \mu \mathrm{g} / \mathrm{mL}\right)$. However, none of the extracts exhibited higher activity than those of the antioxidant standards.

Table 4. Antioxidant activity by the CUPRAC assay ${ }^{\text {. }}$

\begin{tabular}{|l|c|c|c|c|c|c|c|c|}
\hline \multirow{2}{*}{$\begin{array}{l}\text { Extracts / } \\
\text { Concentrations }\end{array}$} & \multicolumn{7}{|c|}{ \% Inhibition in CUPRAC assay } \\
\cline { 2 - 9 } & $\begin{array}{c}\mu \mathrm{g} / \mathrm{mL} \\
\mathrm{CHCl}_{3} \text { extract }\end{array}$ & $25 \mu \mathrm{g} / \mathrm{mL}$ & $\begin{array}{c}50 \\
\mu \mathrm{g} / \mathrm{mL}\end{array}$ & $\begin{array}{c}100 \\
\mu \mathrm{g} / \mathrm{mL}\end{array}$ & $\begin{array}{c}200 \\
\mu \mathrm{g} / \mathrm{mL}\end{array}$ & $\begin{array}{c}400 \\
\mu \mathrm{g} / \mathrm{mL}\end{array}$ & $\begin{array}{c}800 \\
\mu \mathrm{g} / \mathrm{mL}\end{array}$ & $\mathrm{A}_{0.50} \mu \mathrm{g} / \mathrm{mL}$ \\
\hline EtOAc extract & $0.09 \pm 0.01$ & $0.09 \pm 0.01$ & $\begin{array}{c}0.12 \pm 0.0 \\
1\end{array}$ & $0.17 \pm 0.02$ & $0.25 \pm 0.01$ & $\begin{array}{c}0.43 \pm 0.0 \\
4\end{array}$ & $\begin{array}{c}0.74 \pm 0.0 \\
4\end{array}$ & $515.33 \pm 39.56$ \\
\hline $\begin{array}{l}n-\mathrm{BuOH} \\
\text { extract }\end{array}$ & $0.22 \pm 0.04$ & $0.39 \pm 0.09$ & $\begin{array}{c}0.84 \pm 0.1 \\
2\end{array}$ & $1.24 \pm 0.28$ & $2.09 \pm 0.44$ & $\begin{array}{c}2.73 \pm 0.7 \\
2\end{array}$ & $\begin{array}{c}3.64 \pm 0.3 \\
9\end{array}$ & $30.93 \pm 2.50$ \\
\hline BHA $^{\mathrm{b}}$ & $1.12 \pm 0.05$ & $1.95 \pm 0.31$ & $\begin{array}{c}3.14 \pm 0.4 \\
6\end{array}$ & $3.58 \pm 0.42$ & $3.35 \pm 0.20$ & $\begin{array}{c}3.77 \pm 0.1 \\
9\end{array}$ & $\begin{array}{c}3.92 \pm 0.1 \\
3\end{array}$ & $5.35 \pm 0.71$ \\
\hline BHT $^{\mathrm{b}}$ & $1.41 \pm 0.03$ & $2.22 \pm 0.05$ & $\begin{array}{c}2.42 \pm 0.0 \\
2\end{array}$ & $2.50 \pm 0.01$ & $2.56 \pm 0.05$ & $2.86 \pm 0.0$ & $3.38 \pm 0.1$ & $8.97 \pm 3.94$ \\
\hline
\end{tabular}

${ }^{a}$ Values expressed as means \pm S.D. of three parallel measurements. $(p<0.05)$.

${ }^{\mathrm{b}}$ Reference compounds. .

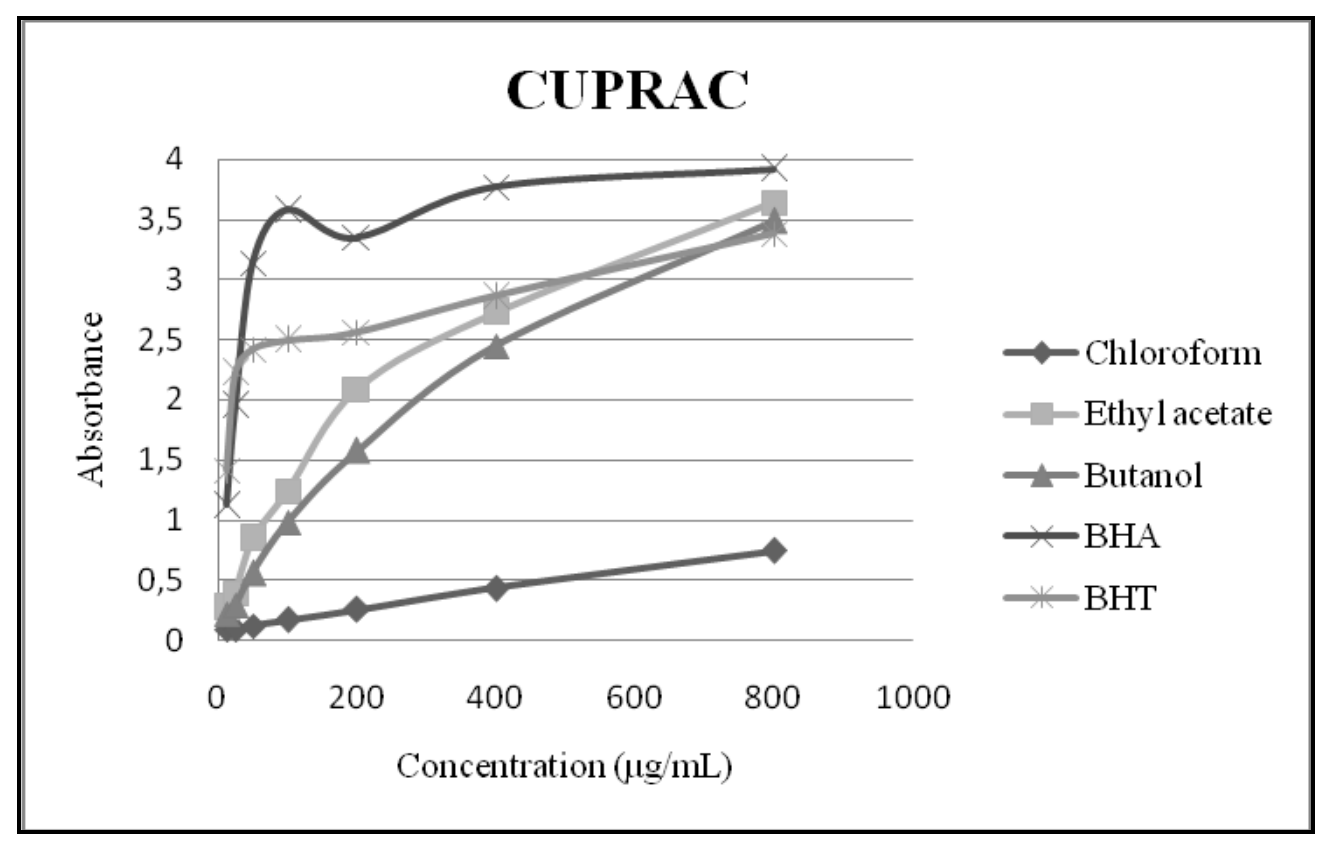

Fig. (4). CUPRAC activity of the three extracts, BHA and BHT at different concentrations (mean $\pm S D, n=3$ ).

\section{CONCLUSION}

The Algerian Centaurea solstitialis ssp. schouwii (DC.) Q. et S. was studied phytochemically for the first time. The antioxidant activities of the $\mathrm{CHCl}_{3}$, EtOAc and $n$ - $\mathrm{BuOH}$ soluble parts of the aqueous- $\mathrm{EtOH}(70 \%)$ extract of the aerial parts were evaluated using two methods, DPPH radical scavenging and CUPRAC. The total phenolic and total flavonoid contents of these extracts were also determined. In comparison to IC $_{50}$ values of BHA $(6.14 \pm 0.41 \mu \mathrm{g} / \mathrm{mL})$, BHT $(12.99 \pm 0.41 \mu \mathrm{g} / \mathrm{mL})$ and $\alpha$-Tocopherol $(13.02 \pm 5.17 \mu \mathrm{g} / \mathrm{mL})$, the ethyl acetate extract exhibited the highest activity $\left(\mathrm{IC}_{50}\right.$ value: $44.01 \pm 1.06 \mu \mathrm{g} / \mathrm{mL}$ ) among the studied extracts, followed by $n$ - butanol extract ( $\mathrm{IC}_{50}$ value: $65.46 \pm 3.07 \mu \mathrm{g} / \mathrm{mL}$ ), in the DPPH assay. The results of CUPRAC assay of the three extracts compared with those of BHA $\left(\mathrm{A}_{0.50}\right.$ value: $\left.5.35 \pm 0.71\right)$ and $\mathrm{BHT}\left(\mathrm{A}_{0.50}\right.$ value: $\left.8.97 \pm 0.71\right)$ showed that among the three extracts, the EtOAc extract exhibited the highest activity $\left(\mathrm{A}_{0.50}\right.$ value: $30.93 \pm 2.50 \mu \mathrm{g} / \mathrm{mL}$ ) followed by $n$-butanol extract $\left(\mathrm{A}_{0.50}\right.$ value: $\left.44.80 \pm 3.74 \mu \mathrm{g} / \mathrm{mL}\right)$. In addition, the $n$-butanol extract had the highest phenolic and flavonoid contents $(130.20 \pm 4.71 \mathrm{mg} \mathrm{GAE} / \mathrm{g}$ extract and $76.97 \pm 6.19 \mathrm{mg}$ QE/g extract, respectively, followed by the ethyl acetate extract, $117.08 \pm 8.54 \mathrm{mg} \mathrm{GAE} / \mathrm{g}$ extract and $54.31 \pm 2.87 \mathrm{mg} \mathrm{QE} / \mathrm{g}$ extract, respectively. Phytochemical investigation of ethyl acetate and $n$-butanol extracts led to the isolation of an undescribed guaianolide named 3-(4-hydroxybenzoyl)- 
cynaratriol (2) together with four known compounds: 4 $\beta$,15-dihydro-3-dehydrosolstitialin A (1), kaempferol 3-O- rhamnoside (3), astragalin (4) and 6-methoxy kaempferol 3-O- $\beta$-glucopyranoside (6-methoxy astragalin) (5).

\section{CONFLICT OF INTEREST}

There are no conflicts of interest.

\section{ACKNOWLEDGEMENTS}

The authors thank DGRSDT and MESRS Algeria, for financial support and the Center of Biotechnology Research, Division of Health, Laboratory of Biochemistry, Constantine, Algeria for the antioxidant activity assays.

\section{REFERENCES}

[1] Khammar, A.; Djeddi, S. Pharmacological and biological properties of Centaurea species. Eur. J. Sci. Res., 2012, 84(3), $398-416$.

[2] Arif, R.; Küpeli, E.; Ergun, F. The biological activity of Centaurea species (review). G U Journal of Science, 2004, 17(4), 149-164.

[3] Yeşilada, E.; Gürbüz, I.; Shibata, H. Screening of Turkish anti-ulcerogenic folk remedies for anti-Helicobacter pylori activity. J. Ethnopharmacol., 1999, 66(3), 289-293.

[4] Albayrak, S.; Atasagun, B.; Aksoy, A. Comparison of phenolic components and biological activities of two Centaurea sp. obtained by three extraction techniques. Asian Pac. J. Trop. Med., 2017, 10(6), 599-606.

[5] Zengin, G.; Cakmak, Y. S.; Guler, G. O.; Aktumsek, A. In vitro antioxidant capacities and fatty acid compositions of three Centaurea species collected from central Anatolia region of Turkey. Food Chem. Toxicol., 2010, 48(10), 2638-2641.

[6] Aktumsek, A.; Zengin, G.; Guler, G. O.; Cakmak, Y. S.; Duran, A. Antioxidant potentials and anticholinesterase activities of methanolic and aqueous extracts of three endemic Centaurea L. species. Food Chem. Toxicol., 2013, 55, 290-296.

[7] Koca, U.; Süntar, I. P.; Keles, H.; Yeşilada, E.; Akkol, E. K. In vivo anti-inflammatory and wound healing activitie of Centaurea iberica Trev.ex Spreng. J. Ethnopharmacol, 2009, 126(3), 551-556.

[8] Zater, H.; Huet, J.; Fontaine, V.; Benayache, S.; Stévigny, C.; Duez, P.; Benayache, F. Chemical constituents, cytotoxic, antifungal and antimicrobial properties of Centaurea diluta Ait. subsp. algeriensis. Asian. Pac. J. Trop. Med., 2016, 9(6), 554-561.

[9] El-Najjar, N.; Dakdouki, S.; Darwiche, N.; El-Sabban, M.; Saliba, N. A.; Gali-Muhtasib, H. Anti-colon cancer effects of salograviolide A isolated from Centaurea ainetensis. Oncol. Rep., 2008, 19(4), 897-904.

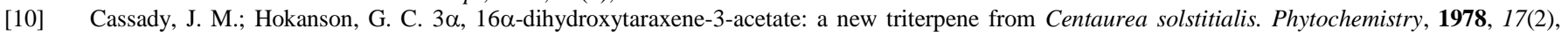
324-325.

[11] Merrill, G.B.; Stevens, K. L. Sesquiterpene lactones from Centaurea solstitialis. Phytochemistry. 1985, 24(9), 2013-2018.

[12] Kamanzi, K.; Raynaud, J. Contribution to the study of the flavone glycosides of Centaurea solstitialis L. Plant Med. Phytother., 1976, $10,78-84$.

[13] Hamburger, M.; Wolfender, J. L.; Hostettmann, K. Search for chlorinated sesquiterpene lactones in the neurotoxic thistle Centaurea solstitialis by liquid chromatography-mass spectrometry, and model studies on their possible artifactual formation. Nat. Toxins, 1993, 1(6), 315-327.

[14] Cassady, J. M.; Abramson, D.; Cowall, P.; Chang, C.; Mc Laughlin, J. L.; Aynehchi Y. J. Centaurepensin: a cytotoxic constituent of Centaurea solstitialis and C. repens (Asteraceae). J. Nat. Prod., 1979, 42(4), 427-429.

[15] Erenler, R.; Sen, O.; Sahin Yaglioglu, A.; Demirtaş, I. Bioactivity-guided isolation of antiproliferative sesquiterpene lactones from Centaurea solstitialis L. ssp. solstitialis . Comb. Chem. High. Throughput Screen, 2016, 19, 66-72.

[16] Yeşilada, E.; Gürbüz, I.; Bedir, E.; Tatli, I.; Khan, I. A. Isolation of anti-ulcerogenic sesquiterpene lactones from Centaurea solstitialis L. ssp. solstitialis through bioassay-guided fractionation procedures in rats. J. Ethnopharmacol., 2004, 24(2-3), 213-219.

[17] Özçelik, B.; Gürbüz, I.; Karaoglu, T.; Yeşilada, E. Antiviral and antimicrobial activities of three sesquiterpene lactones from Centaurea solstitialis L. ssp. solstitialis. Microbiol. Res., 2009, 164(5), 545-552.

[18] Gürbüz I, Yeşilada E. Evaluation of the anti-ulcerogenic effect of sesquiterpene lactones from Centaurea solstitialis L. ssp. solstitialis by using various in vivo and biochemical techniques. J. Ethnopharmacol, 2007, 112(2), 284-291.

[19] Kilic, O. Essential oil compounds of three Centaurea L. taxa from Turkey and their chemotaxonomy. J. Med. Plants Res., 2013, 7(19),1344-1350.

[20] Bruno, M.; Diaz, J. G.; Herz, W. Guaianolides and lignans from Centaurea solstitialis subsp. schouwii. Phytochemistry, 1991, 30(12), $4165-4166$.

[21] Oksüz, S.; Glark, R. J.; Herz, W. A guaianolide diol monoacetate from Centaurea behen and C. solstitialis ssp. schouwii. Phytochemistry, 1993, 33(5), 1267-1268.

[22] Senatore, F.; Formisano, C.; Raio, A., Bellone, G.; Bruno, M. Volatile components from flower-heads of Centaurea nicaeensis All., C. parlatoris Helder and C.solstitialis L. ssp. schouwii (DC.) Dostál growing wild in southern Italy and their biological activity. Nat. Prod. Res., 2008, 22, 825832 .

[23] Licata, M.; Tuttolomondo, T.; Leto, C.; Virga, G.; Bonsangue, G.; Cammalleri, I.; Gennaro, M. C.; La Bella, S. A survey of wild plant species for food use in Sicily (Italy) results of a 3-year study four regional parks. J. Ethnobiol. Ethnomed., 2016, 12(12), 14 pages.

[24] Boussaha, S.; Bekhouche, K.; Boudjerda, A.; León, F.; Koldaş, S.; Yaglioglu, A. S.; Demirtaş, I.; Brouard, I.; Marchioni, E.; Zama, D.; Benayache, S.; Benayache, F. Chemical constituents, in vitro antioxidant and antiproliferative activities of Perralderia coronopifolia Coss. subsp. eu-coronopifolia M. var. typica M. extract. Rec. Nat. Prod., 2015, 9(3), 312-322.

[25] Aliouche, L.; Larguet, H.; Amrani, A.; León, F.; Brouard, I.; Benayache, S.; Zama, D.; Meraihi Z. ; Benayache, F. Isolation, antioxidant and antimicrobial activities of ecdysteroids from Serratula cichoracea. Curr. Bioact. Compd., 2018, 14(1), 60-66.

[26] Seghiri, R.; Boumaza, O.; Mekkiou, R.; Benayache, S.; Mosset, P.; Quintana, J.; Estévez, F.; León, F.; Bermejo, J.; Benayache, F. A flavonoid with cytotoxic activity and other constituents from Centaurea africana. Phytochem. Lett., 2009, 2(3), 114-118.

[27] Hammoud, L.; Seghiri, R.; Benayache, S.; Mosset, P.; Lobstein, A.; Chaabi, M.; León, F.; Brouard, I.; Bermejo, J.; Benayache, F. A new flavonoid and other constituents from Centaurea nicaeensis All. var. walliana M. Nat. Prod. Res., 2012, 26(3), 203-208.

[28] Kolli, E. H.; León, F.; Benayache, F.; Estévez, S.; Quintana, J.; Estévez, F.; Brouard, I.; Bermejo, J. ; Benayache, S. Cytotoxic sesquiterpene lactones and other constituents from Centaurea omphalotricha. J. Braz. Chem. Soc., 2012, 23(5), 977-983.

[29] Bicha, S.; Chalard, P.; Hammoud, L.; León, F.; Brouard, I.; Garcia, V. G.; Lobstein, A.; Bentamene, A.; Benayache, S.; Bermejo, J.; Benayache, F. Maroccanin: a new $\alpha$-lactone and other constituents from Centaurea maroccana Ball. (Asteraceae). Rec. Nat. Prod., 2013, 7, 114118.

[30] Baali, N., Baali, S., Bentamen, A., Benayache, S., Benayache, F., Amedah S. Ameliorative effect of Centaurea maroccana and Centaurea acaulis against nephrotoxicity induced by carbon tetrachloride. Curr. Bioact. Compd., 2018. DOI : 10.2174/1573407214666180820151905.

[31] Quezel, P. ; Santa, S. Nouvelle flore de l'Algérie et des régions désertiques méridionales. Editions du C.N.R.S, Paris, $1963,2,1026$. 
[32] Slinkard, K.; Singleton, V.L. Total phenol analyses: automation and comparison with manual methods. Am. J. Enol. Viticult., 1977, $28,49-55$.

[33] Turkoglu, A.; Duru, M. E.; Mercan, N.; Kivrak, I.; Gezer, K. Antioxidant and antimicrobial activity of Laetiporus sulphurous (Bull.) Murrill. Food Chem., 2007, 101(1), 267-273.

[34] Blois, M. S. Antioxidant determinations by the use of a stable free radical. Nature, 1958, 181, 1199-1200.

[35] Apak, R.; Guclu, K.; Ozyurek, M.; Karademir, S. E. Novel total antioxidant capacity index for dietary polyphenols and vitamins $\mathrm{C}$ and $\mathrm{E}$, using their cupric ion reducing capability in the presence of neocuproine: CUPRAC method. J. Agric. Food Chem., 2004, 52(26), 7970-7891.

[36] Bernhard, H. O.; Thiele, K.; Pretsch. E. Cynaratriol, ein neues Guajanolid aus der Kardone Cynara cardunculus L. und der Artischocke C. scolymus L. (Compositae). Helv. Chim. Acta., 1979, 62(4), 1288-1297.

[37] López-Rodríguez, M.; García, V.P.; Zater, H.; Benayache, S.; Benayache, F. Cynaratriol, a sesquiterpene lactone from Centaurea musimomum. Acta. Cryst., 2009, E65, o1867-o1868.

[38] Zater, H. Magister Thesis, November 2004, University Mentouri, Constantine, Algeria.

[39] Stevens, K. L.; Witt, S. C.; Kunt, S.; Haddon, W. F.; Benson, M. Picrolide A, an unusual sesquiterpene lactone from Acroptilon repens. J. Nat. Prod., 1991, 54(1), 276-280.

[40] Öksüz, S.; Topcu, G. Guaianolides from Centaurea glastifolia. Phytochemistry, 1994, 37(2), 487-490.

[41] Medjroubi, K.; Benayache, F.; León, F.; Bermejo, J. Complete assignment of the ${ }^{13} \mathrm{C}$ of ${ }^{1} \mathrm{H}$ NMR spectra of two Known guaianolides isolated from Centaurea musimomum. Rev. Colomb. Quim., 2003, 32, 17-25.

[42] Diantini, A.; Subarnas, A.; Lestari, K.; Halimah, E.; Susilawati, Y.; Supriyatna, S.; Julaeha, E.; Achmad, T. H.; Suradji, E. W.; Yamazaki, C.; Kobayashi, K.; Koyama, H.; Abdulah, R. Kaempferol 3-O -rhamnoside isolated from the leaves of Schima wallichii Korth. Inhibits MCF-7 breast cancer cell through activation of the caspase cascade pathway. Oncol. Lett., 2012, 3(5), 1069-1072.

[43] Chemam, Y.; Benayache, S.; Marchioni, E.; Zhao, M.; Mosset, P.; Benayache, F. On-Line screening, isolation and identification of antioxidant compounds of Helianthemum ruficomum. Molecules, 2017, 22, 239, doi:10.3390/molecules22020239.

[44] Wei, X.; Huang, H.; Wu, P.; Cao, H.; Ye, W. Phenolic constituents from Mikania micrantha. Biochem. Syst. Ecol., 2004, 32(11), 1091-1096. 